\title{
Al-Turas
}

\section{Cultural Transplantation and Legal Paradox: The Case of the Indonesian Judicial Commission Versus the Supreme Court}

\author{
JM. Muslimin \\ Universitas Islam Negeri Syarif Hidayatullah \\ Jakarta, Indonesia \\ jm.muslimin@uinjkt.ac.id
}

\begin{abstract}
The purpose of this research was to prove that solving a legal problem needed an interdisciplinary approach, more than merely pure law. It relates to the working culture of law, inter-subjective understanding and reform willingness. The research was done based on descriptive and qualitative method. It included content analyses of the use and misuse concept of regulation, its effect in actual practice and cultural barrier of law enforcement. The finding of this research proved that law enforcement was not like copying a paper. It related closely to the tradition, usage and custom of people. Transforming society only by introducing new regulation and state institution without cultural restoration ended in failure. Thus, the conclusion was the establishment of Judicial Commission in Indonesia, aimed at transforming the Supreme Court, to be more independent, impartial and accountable by supervising the ethical behaviour of the judge. But Judicial Commission is hampered by many difficulties legally and institutionally. Judicial Commission could not work and achieve its goal to bring about Supreme Court more transparent, not only because of legal obstacles but also cultural impunity.
\end{abstract}

Keywords: Culture, Judicial Commission, Supreme Court, Legal Paradox 
JM. Muslimin, Cultural Transplantation and Legal Paradox: The Case of the Indonesian Judicial Commission Versus the Supreme Court

\begin{abstract}
Abstrak
Penelitian ini bertujuan untuk membuktikan bahwa penyelesaian suatu masalah hukum memerlukan pendekatan interdisipliner, lebih dari sekedar ilmu hukum murni. Ini berkaitan dengan budaya kerja hukum, pemahaman inter-subjektif dan kemauan reformasi. Penelitian ini dilakukan dengan metode deskriptif kualitatif. Ini mencakup analisis konten mengenai penggunaan dan penyalahgunaan konsep regulasi, dampaknya pada praktik nyata serta hambatan budaya penegakan hukum. Temuan penelitian ini membuktikan bahwa penegakan hukum tidak seperti menyalin tulisan. Penegakan hukum memiliki hubungan erat dengan tradisi, dan adat istiadat masyarakat. Mengubah masyarakat dengan hanya memperkenalkan regulasi baru dan lembaga negara tanpa restorasi budaya akan berakhir dengan kegagalan. Dengan demikian, dapat disimpulkan bahwa pembentukan Komisi Yudisial (KY) di Indonesia bertujuan untuk membuat Mahkamah Agung (MA) menjadi lebih independen, imparsial, dan akuntabel dengan mengawasi perilaku etis hakim. Namun dalam praktiknya KY menghadapi banyak hambatan secara hukum dan kelembagaan. KY tidak dapat bekerja dan mencapai tujuannya untuk mewujudkan MA yang lebih transparan disebabkan oleh tidak hanya hambatan legal tapi juga impunitas budaya.
\end{abstract}

Kata kunci: budaya; Komisi Yudisial; Mahkamah Agung; paradoks hukum

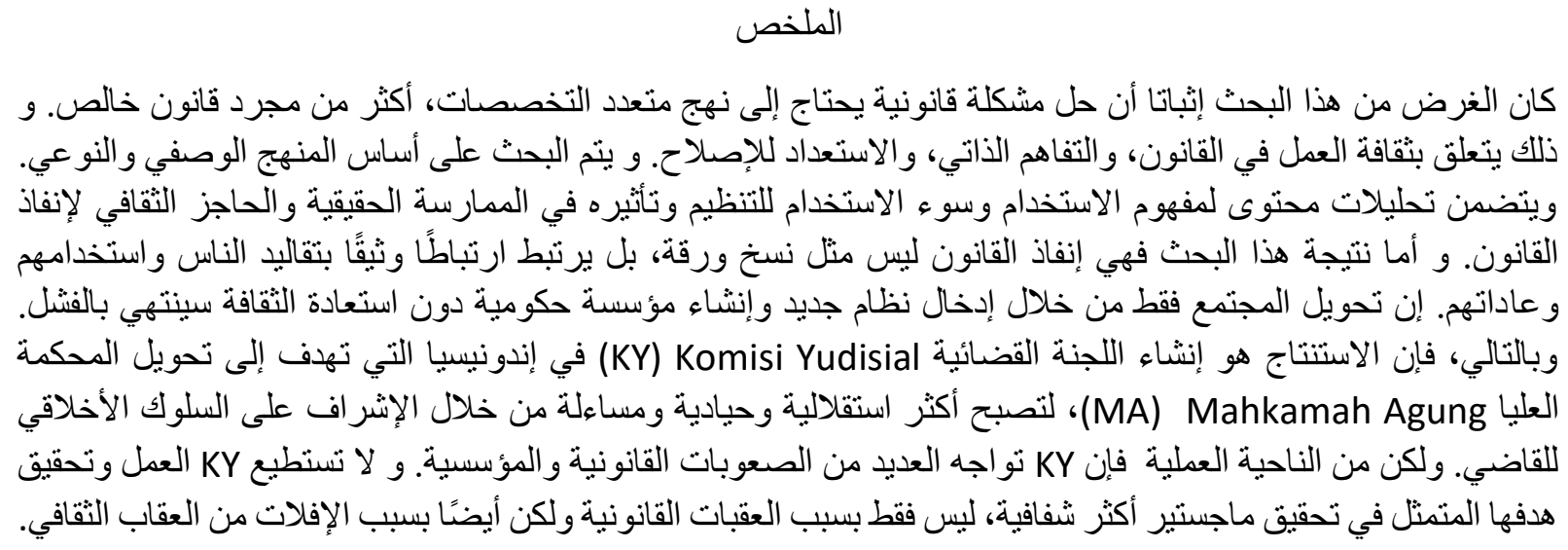




\section{INTRODUCTION}

In the study of jurisprudence, the substance of law comprises a set of legal norms, whether they are written legal norms, commonly known as legislation or unwritten rules. Included in this substance is a product of the legal system itself, such as jurisprudence or decisions with a variety of variants and its derivatives or regulations adopted by the agents of the law when they apply the law and its relations. When a trader agrees with one another, for example, or when a president signs a memorandum of cooperation or other important decisions, then he bases all of it on the related regulations in trade, government, etc. In short, all of the rules are commonly referred to as a legal substance (Cotterrell, 2017a; Friedman, 1977; Priban, 2017).

The legal structure is also closely related to the law enforcement. It is directly related to the organization or bureaucracy that sustains the enforcement or - borrowing Hans Kelsen's phrase - that is to realize its (Konkretisierung) substance of law to achieve an aspired justice (Kelsen, 1979). This structure is usually known as the "administration of justice". Talking about the structure of administrative law or the law to achieve this justice cannot be separated by a discussion of the judicial system itself, together with supporting infrastructure closely associated with it. Usually, in a country revived by a modern conception of modern state administration or the welfare state, the supporting infrastructure of the legal structure (criminal) is the police (investigator), prosecutor, the court (the judge), lawyer (lawyers/defenders) and prison (rehabilitator) (Dias, 1976; Raz, 1973).

Legal culture can be described as the "software" of substance and structure of the law itself. It is closely associated with the culture of the society, the ideal expectation of some form of intended community, values and beliefs that are behind the visible legal tradition. Including the legal culture is also understanding, perception, acceptance attitude and practice acceptance, awareness, emotion or obedience, and attitudes towards governance (legal structure) and the law itself (the substance of the law) (Chambliss \& Seidman, 1971; Radbruch, 1961).

The ideal of legal change will fail if it is only related to changes in the content or legal structure, but it has to touch on all three elements (content, structure and legal culture) simultaneously. The change in legislative texts (legal content) is not alter the work mechanism and administration of legal institutions (legal structure), let alone to change the perception or legal understanding of society (legal culture). It occurs often, a set of texts of legislation and regulations that have contained the ideal normative values that have been completed and put into effect, but because of the institutional apparatus and unprofessional personnel, the legislation stops to be in effect (Algra, N., 1981).

During the New Order era, thoughts on Trias Politica were well known. But in the practical level, the separation of powers based on the Trias Politica had not gone as expected. The New Order regime was fully controlled and dominated by the executive line, while the legislative and judicial powers operated as if they were only legal accessories. Thirty years more such governance practices had proceeded, to where the correction for these deviations had surfaced and reached its peak in 1998 with the coming of the era known as the reform era.

One product of the reform era is the birth of the Assembly Decree of The People's Consultative Assembly (Ketetapan Majelis Permusyawaratan Rakyat/TAP MPR) which contains the principle of development reform in rescuing and normalizing national life as a state policy (TAP MPR No X / MPR / 1998). It stresses the need for a cut and clear separation between the three institutions of power (executive, legislative and judiciary), so that each function can be ideal and give birth to proper governance practices. For this purpose, it is 
JM. Muslimin,

Cultural Transplantation and Legal Paradox: The Case of the Indonesian Judicial Commission

Versus the Supreme Court

deemed necessary to amend the Constitution (Undang Undang Dasar) and related regulatory changes. Thus, Judicial Commission was born. Its primary task is to protect the independence, impartiality and accountability of The Supreme Court and judiciary by supervising the dignity and noble character and behaviour of judges.

In practical level, the ideal purpose of establishing Judicial Commission has some sociocultural obstacles. Therefore, this article is written in order to answer the following research questions: how is the inter-cultural relation between law, politics and tradition of good governance; what are the cultural barriers of Judicial Commission in supervising Supreme Court? why Supreme Court has a socio-legal impunity, that it can easily avoid Judicial Commission's control?; what should be done to apply "check and balanced" system by employing Judicial Commission to be a sparring partner of Supreme Court in order to erase legal paradox?

\section{METHOD}

The research is done based on descriptive and qualitative approach. It includes content analyses of the concept of regulation, its effect in actual practice and cultural barrier of law enforcement. It begins by describing the tradition of good and bad governance, the interrelation of culture and law enforcement, and the use and misuse of law. The following step is the elaboration of job and task of Supreme Court and Judicial Commission in accordance to the rule of law. After describing the task, the writing shows detailed daily tension of Supreme Court and Judicial Commission in carrying their duties, so that the 'forced' cultural transplantation and legal paradox is clearly illustrated. The explorations end with some academic options of solutions.

The end of this research will show that tension and conflict between Judicial Commission and Supreme Court have to be resolved. Judicial Commission has its own duties that must be respected. By referring to theories of Max Weber, there are four elements of rational law: rational substance, rational procedure, irrational substance, irrational procedure. If the tension and conflict cannot be resolved rationally, the two institutions cannot be called as rational products. Therefore, they may be labelled as institutions with legal and cultural paradox. The rational approach will lead the cultural transplantation of a legal system towards sound institutional interrelation. Some ideas for solving rationally are the end points of the article.

\section{FINDINGS AND DISCUSSION}

\section{Judicial Commission as a Solution: The Interrelation of Law, Politics and Corruption}

Among the worst social disease, corruption in Indonesia is that attacking its legal structure (police, prosecutors, courts). National Survey on corruption conducted by the Partnership for Governance Reform in Indonesia, in 2002, showed how bad the law enforcers were. A survey that involved 650 respondents of civil servants, 400 private employees, and 1,250 citizens concluded that the judicial bodies and the judiciary were regarded as the most corrupt public institutions. According to the survey, judges and prosecutors, individually and institutionally, were considered the most corrupt in Indonesia. They were slightly better than the traffic police and custom (Tim Penyusun, 2005). The case is not decreasing even until today. 
Daniel Kaufmann, an observer of the law and legal institutions in developing countries, in a survey of bureaucratic and judicial bribery also stated that bribery in the judicial system in Indonesia was the highest when compared to countries prominently controlled by agents and narcotics mafia such as Colombia, Venezuela or the former communist states of Ukraine and Russia or semi-dictatorial countries such as Egypt and Jordan (Tim Penyusun, 2005).

On the corruption in the judiciary or commonly known as the legal mafia, it has plagued the judicial process from upstream to downstream, at all stages, starting from the inquiry and investigation by police in a criminal case, investigation, filing and transfer of cases to the court by prosecutor to the case and court sessions and judge's verdict in the court. Even until after the verdict is given to the defendant/suspect that he is convicted, there is still a chance to make a transaction of legal execution with the prosecution or prison authorities (Zakiyah \& dkk, 2003).

Briefly, in order that prosecutors and judges can also be designed under the plot, then a lawyer strengthens and fully supports these actions. The chronology and sequence of cases from the early start have been prepared by the police to aim the target with such technical modifications and technicalities in the existing legal formal and material. Even it is not impossible for a real defendant / suspect, in the process of investigation by the police, can be set free as long as he understands the case 'charge' that should be 'paid' (Kompas, 2007; Rahardjo, 2002; Tim Penyusun, 2005).

The judiciary performance cannot be proud of and has not been regarded positively by the public. Prosecutors issue Warrant Termination of Investigation for cases (through "common sense") which is not really difficult to be categorized as an act of corruption that hurts the public's sense of justice. Not to mention, many legal cases handled by the judiciary are put down in court and declared the charges not proven and the defendant should be released from all claims (onslag van rechtsvervolging) just because of the letter and the charge content made by the judiciary have been formulated in such a way that from beginning have not been impartial aim and do not really favor the law and justice.

The condition of judges and lawyers is also not much different from the reality in the ranks of police and prosecutors. Nets and snares of money, power intervention, lobby, case transactions and case brokers are everyday vocabularies as if they have been institutionalized that exceed their formal institutions themselves. Thus, in the ranks of the Supreme Court it is seen clearly how a legal case and concerning the corruption, circulates and is 'circulated' among the networks. In short, the condition of the police and prosecutors, judges, lawyers and the judicial system themselves, from the first level to the highest one, cannot eliminate a lot of mysterious things that perpetuate mistrust spaces.

This condition is aggravated by the acts of some politicians and political institutions. The politicians and main institutions of democracy have been entangled in the mud and enjoyment of corruption. Directly supporting Regional Head Election (Election), the recruitment of candidates for state officials through a fit and proper test, specific discussion of the Legal Draft (Rancangan Undang Undang), even the recruitment of candidates for the internal legislative members of political party become an excellent opportunity to the flourishing of political transactions drawing no little amount of money.

Do these conditions happen also in the recent years and until now? Unfortunately, the situation is not getting better. It is easy to find data telling us that those institutions are remaining almost the same. Anyone can search and prove easily by accessing daily news concerning the issue. The situation is getting worst. Since the Commission for Eradicating Corruption is infiltrated and trapped in proxy-war, it is decontaminated by negative opinion building through 
JM. Muslimin,

Cultural Transplantation and Legal Paradox: The Case of the Indonesian Judicial Commission

Versus the Supreme Court

parliamentary session and voices and marginalized, threatened, isolated by the act of internal splitting and external destruction (Republika, 2017); (Kompas, 2007).

In short, the same thing happens with the law enforcement process, the political processes are hard to be considered running normally according to political market mechanism. The invisible hands in any recruitment of cadres, leaders, succession of central board are full of money politics. The recruitment and the political processes themselves have become gold mine and industry of very promising corruption.

\section{The Existence of the Judicial Commission and the Supreme Court: A Legal Framework}

The institutional existence of the Judicial Commission in the Indonesian constitutional legal system is contained in Chapter IX of the 1945 Constitution, the result of an amendment governing judicial power. Judicial Commission is a new state institution that did not exist before the amendment. Article 24B of the 1945 Constitution states that:

1. The Judicial Commission is independent and has the authority to propose the appointment of justices and has other powers in maintaining and upholding honour, dignity, and judicial behaviour.

2. Members of the Judicial Commission must have knowledge and experience in the legal field and possessing impeccable integrity and personality.

3. Members of the Judicial Commission are appointed and dismissed by the President with the approval of the House of Representatives.

4. The composition, position and membership of the Judicial Commission are regulated by law.

Judicial Commission provisions in Chapter IX which regulate judicial power does not mean that KY is an institution of judicial authority. Based on Article 24 paragraph (2) of the 1945 Constitution the amendment results determined that the judicial authority is carried out by a Supreme Court and the judiciary below it in the general court, religious court, military court, state administration court, and by a constitutional court.

Looking at the social settings that have been described previously, it can be said that the existence of Judicial Commission is in order to support the creation of a truly independent judiciary, able to uphold law and justice, while answering the pessimism and mistrust of the public towards the independence of justice. If reflected in several countries, such as Australia, Italy, Spain and Portugal, institutions such as Judicial Commission can play a constructive role in maintaining and enhancing the professionalism of judges and the judiciary (Kioukies, 2020).

Thus, it can be stated that the existence of Judicial Commission is motivated and functions as; first, the lack of intensive monitoring of judicial authority, because monitoring is only done internally; second, the absence of institutions that serve as a link between government power (executive power) and judicial power (judicial power); third, judicial power is considered inefficient in carrying out its duties if it is still preoccupied with technical non-legal issues; fourth, it often found that there is no consistency in judicial institutions' decisions, because each decision lacks the rigorous evaluation and supervision of a specialised institution; fifth, the pattern of recruitment of judges has so far been considered to be potentially politically contaminated, because the institutions that proposed and recruited it were political institutions, namely the president and parliament; Sixth, related to the honour and dignity of judges, it is not only interpreted as the need for monitoring and supervision, but can also be interpreted as 
maintaining competence and professionalism. Here, it is deemed necessary to have an institution that can do that by providing training and programs that focus on fostering ethics and integrity and competence outside the judiciary itself.

The existence and function of Judicial Commission has become increasingly clear with the existence of Law (Law) Number 22 of 2004 which was later amended by Law Number 18 of 2011 concerning Judicial Commission. Article 20 paragraph (1) of the Act confirms that:

1. In order to maintain and uphold the honour, dignity, and behaviour of Judges, the Judicial Commission has the task of:

a. monitoring and supervising the behaviour of Judges;

b. receiving reports from the public relating to violations of the Code of Ethics and / or the Code of Conduct for Judges;

c. verifying, clarifying, and investigating reports of alleged violations of the Code of Ethics and / or Judges' Code of Conduct in private;

d. deciding whether or not a report of alleged violation of the Code of Ethics and / or the Judge's Code of Conduct is true and;

e. taking legal steps and / or other steps against individuals, groups of people, or legal entities that humiliate the honour and dignity of the Judge.

The existence of the Supreme Court is as old as the existence of Indonesia. The Supreme Court in the history of the constitutional journey of the Republic of Indonesia (RI) is one of the state institutions that has always existed and is regulated in constitutions that have been in force in Indonesia starting from the 1945 Constitution which was ratified on 18 August 1945 (including the 1945 Constitution after the Decree of 5 July 1959), the Constitution of the United States of Indonesia (KRIS) 1949, the Provisional Constitution (UUDS) of 1950 and the 1945 Constitution of Amendment Results. In the amendment of the 1945 Constitution, the existence of the Supreme Court is regulated in Article 24 paragraph (2) and Article 24 A, including Article 14 paragraph (1) which regulates granting clemency and rehabilitation from the President. Article 24 paragraph (2) of the amendment of the 1945 Constitution states expressly that, "Judicial power is exercised by a Supreme Court and the judiciary below it within the general court, religious court, military court, state administration court,... " Whereas Article 24A of the 1945 amendment stipulates that:

1. The Supreme Court has the authority to adjudicate at the cessation level, examine the statutory provisions under the law against the law, and have other powers granted by law.

2. The Supreme Court Justices must have integrity and personality that are impeccable, fair, professional and experienced in law.

3. Prospective Supreme Court Judges are proposed by the Judicial Commission to the House of Representatives to get approval and subsequently be appointed as Chief Justice by the President.

4. The chair and deputy chair of the Supreme Court are chosen from and by the Supreme Court judge.

5. The composition, position, membership and procedural law of the Supreme Court and the judiciary below are regulated by law.

Regarding judicial authority itself, the 1945 Constitution of the Republic of Indonesia (1945 Constitution) because of the amendment confirms "Judicial power is the power of an independent state to administer justice to enforce law and justice". In Law No. 48 of 2009 concerning Judicial Power also states that, 
JM. Muslimin,

Cultural Transplantation and Legal Paradox: The Case of the Indonesian Judicial Commission

Versus the Supreme Court

"Judicial Power is the power of an independent state to administer justice in order to enforce law and justice based on the Pancasila and the 1945 Constitution of the Republic of Indonesia, for the sake of implementing the Republic of Indonesia's Law State."

The Supreme Court as one of the highest judicial powers of the state has a strategic position and role in judicial power because it oversees not only 4 (four) judicial environments but also management in the administrative, personnel and financial fields and facilities and infrastructure. The "one roof" policy provides responsibilities and challenges because the Supreme Court is demanded to show its ability to create professional, effective, transparent and accountable institutional organisations. For this matter, the Supreme Court has an internal control authority attached to the level and structure and functional internal controls within the Supreme Court Supervisory Agency. The responsibilities of the Supreme Court are contained in Law No. 35 of 1999 concerning Amendment to Law No. 14 of 1970 on the Basic Provisions of Judicial Power, and has been revised by Law No. 4 of 2004, and being revised through Law No. 48 of 2009 concerning Judicial Power.

\section{Daily Behavior and Cultural Paradox: Law and Episodes of Drama}

Disharmony took place between the Supreme Court and the Judicial Commission in carrying out its supervisory duties and functions beginning in 2005, when the Judicial Commission took action in order to supervise the judges of the West Java High Court, after Depok regional election case. The judges annulled Nurmahmudi Ismail's victory as the mayor of Depok. Judicial Commission sent a recommendation to the Supreme Court to fire the head of the panel of judges (who is also the chairperson of PT of West Java) and gave a written warning. However, the Supreme Court did not immediately follow up the Judicial Commission recommendations, if Judicial Commission threatened to send a reprimand to the Supreme Court.

In the same year, Chief Justice of the Supreme Court, Bagir Manan, refused to fulfil the Judicial Commission summons related to the alleged bribery case by Probosutedjo with Arthaloka land dispute. Conditions became even more heated when KY proposed the idea of a re-selection of justices. The Judicial Commission, accompanied by Minister of Justice and Human Rights Hamid Awaluddin, met with President Susilo Bambang Yudhoyono to discuss the re-selection. They advised the president to issue an alternative regulation (Peraturan Pemerintah Pengganti Undang-undang/Perppu) as a legal basis. However, the Perppu that they requested in the end was never published.

Prolonged chaos never subsided. The media reported 13 (thirteen) Supreme Court Justices that were considered to be problematic based on information of Judicial Commission. The news sparked the anger of the Supreme Court. The judges who were named revealed reported Judicial Commission (Detik, 2005a; Merdeka, 2005; Detik, 2005b; Suaramerdeka, 2005; Detik, 2006; Hukumonline, 2006) Chief Busyro Muqodas to the Police on charges of defamation. The dispute continued when 40 justices in March 2006 filed a petition for judicial review of Law No. 22 of 2004 concerning the Judicial Commission to the Constitutional Court.

For the judges, Article 4 B of the 1945 Constitution is not intended for Supreme Court Justices and Constitutional Justices. The provisions in the Judicial Commission Act and the Judicial Power Law which regulates that the Judicial Commission has the authority to supervise Supreme Court Justices and Constitutional Justices is seen as contradictory to Article 24 B (1) of the 1945 Constitution. The Constitutional Court granted some of the petition's claims. 
However, according to the Court, justices are included in judges who are monitored by Judicial Commission.

In 2010, Judicial Commission attempted to examine 7 (seven) Supreme Court Justices who were considered to have violated the code of ethics and the code of conduct of judges. However, the judges refused to attend the hearing. They are Paulus Effendy Lotulung, Djoko Sarwoko, Ahmad Sukarja, I Made Tara, Mansur Kartayasa, Hakim Nyak Pha, and Imam Soebechi. In 2012, the conflict declined slightly, even considered the best period in the history of the Supreme Court and Judicial Commission relations. The proof four joint regulations were successfully agreed upon and signed. This is inseparable from the role of the liaison team formed by the two institutions. The team is tasked with discussing and accommodating all issues that should be discussed between the two institutions.

Then Supreme Court - Judicial Commission relations heated up again in 2015. In January 2015, public attention was focused on the Supreme Court Judge Timur Manurung who was questioned by the Corruption Eradication Commission related to a case of alleged bribery in the recommendation of exchanging forest areas in Bogor. He was examined as a witness. He was also reportedly having dinner with a corruption defendant and a lawyer at a restaurant on Jalan Sudirman, Jakarta. The Chief Justice did not want to comment on the case. However, Judicial Commission has formed an investigation team. Timur also threatened to report Judicial Commission commissioners to the Police (Kompas, 2015; Detik, 2015).

February 2016, Judicial Commission and Supreme Court were also involved in differences of opinion with Sarpin Rizaldi, a judge at the South Jakarta District Court, who accepted General Budi Gunawan's pre-trial lawsuit. Judge Sarpin expanded the pre-trial object where the determination of the suspect could be used as a pre-trial object. The verdic seized public attention. Judicial Commission criticized and planned to examine Judge Sarpin for allegedly violating the code of ethics and good behaviour of judges (Kode Etik dan Pedoman Perilaku Hakim/KEPPH) while the Supreme Court insisted it would not examine Sarpin. In March 2015, the Supreme Court Justices who were members of the Indonesian Judges Association submitted a judicial review of the Judicial Commission.

They questioned the rules that gave the Judicial Commission authority to be involved in the selection of appointing judges with the Supreme Court in three judicial environments through judicial review to the Constitutional Court. The Indonesian Judges Association (IKAHI) requests the review of Article 14A paragraph (2), (3) of Law no. 49 of 2009 concerning General Judiciary, Article 13A paragraph (2), (3) of the Law No. 50 of 2009 concerning Religious Courts and Article 14A paragraph (2), (3) of Law no. 51 of 2009 concerning State Administrative Court (PTUN). According to IKAHI, the authority of the Judicial Commission in the selection process for selecting judges degrades the role of IKAHI to maintain the independence guaranteed by Article 24 of the 1945 Constitution. In addition, Article 21 of the Judicial Power Law states that the organisation, administration, and finance of the Supreme Court and the judiciary are under the authority of the Supreme Court. The IKAHI step has come under fire from many parties. A few months before IKAHI submitted this judicial review, the Supreme Court and the Judicial Commission had agreed to the draft MA-KY Joint Regulation on the Selection of Appointment of Judges, only to be signed by the Supreme Court.

Then there was another conflict related to the Supreme Court's refusal of the recommendation submitted by Judicial Commission to the Chief Justice regarding the Antasari Azhar case, which requested that the panel of judges of the Antasari Azhar case be prohibited from handling cases for 6 months alias "non-hammer judges." The decision was taken at the 
JM. Muslimin,

Cultural Transplantation and Legal Paradox: The Case of the Indonesian Judicial Commission

Versus the Supreme Court

Supreme Court's plenary meeting (cnnindonesia, 2015); (Hukumonline, n.d.). 17 In this case even before, Judicial Commission planned to submit a Dispute Authority between State Institutions (Sengketa Kewenangan Lembaga Negara /SKLN) to the Court to request an assessment of whether the Supreme Court leadership meeting had the right to refuse a decision on Judicial Commission recommendations since the meeting was not the trial panel of judges, but a part of leadership of the Supreme Court which was merely administrative.

However, besides the conflict between the two institutions in the supervision of judges, the Indonesian Supreme Court and the Indonesian Judicial Commission have also established cooperation in supervising judges in Indonesia. First, the ratification of Law No. 48 of 2009 concerning Judicial Power, Law No. 3 of 2009 concerning the Second Amendment to Law No, 14 of 1985 concerning the Supreme Court and a number of changes to the laws and regulations of all judicial bodies under the Supreme Court, as well as the drafting of a Joint Decree on the Code of Ethics and the Code of Conduct for Judges. Secondly, the ratification of Law No. 18 of 2011 concerning Amendments to Law No. 22 of 2004 concerning the Judicial Commission; and third, four joint regulations emerged with the Supreme Court and the Judicial Commission of the Republic of Indonesia No. 01/PB/MA/IX/2012-01/PB/P.KY/09/2012 Regarding the Appointment of Judges, No. 02/PB/MA/IX/2012-02/PB/P.KY/09/2012 Regarding Guidelines for Enforcing the Code of Ethics and the Code of Conduct for Judges, No. 03/PB/MA/IX/201203/PB/P.KY/09/2012 Regarding the Procedures for Joint Examination, No. 04/PB/MA/IX/ 2012-04/PB/P.KY/09/2012 Regarding Formation, Work Procedures and Procedures for Decision Making of Honorary Judges.

\section{Cultural-Based Perspectives on Law: Offering Solutions}

Learning from the history and difficulties of the relationship between Judicial Commission and Supreme Court above, some notes deserve to be underlined. First, strengthening the determination to practise law based on the vision and mission of the nation amid the challenges of changing times and freeing oneself from the dogmatic legal tradition of Begriffsjurisprudenz. Begriffsjurisprudenz's legal tradition teaches that the main points of law, legal reasoning and application of law are developed from existing concepts through merely a logical approach, to give a strong impression of the power of the law to carry out an expansion of logic itself amid social reality. In such a perspective, every act of deduction and application of a law that is most important to note is the integration of positivist and logical coherence of interpretations only (Erzeugungszusammenhang). In short, the law is revoked from the ethical goals and macromorality-socio-economic-national-purpose setting in the name of logic and positivist coherence of the law itself. In fact, even progressive methods and legislation, but in the hands of law enforcers who lack integrity and comprehensive skills, will continue to create sustainable social and legal anomalies. The legal method is not in a space. It depends on who will be behind the method itself (the man behind the gun). In this context, it is actual if Taverne (Dutch legal expert) states: Geef me goede Rechters, goede Officieren van Justitie, goede Rechter Commisarissen en goede a good judge, a good prosecutor, a good commissioner judge and a good police officer, so I will make bad criminal procedural law become good). All parties deserve to be careful of the entrapment of Begriffsjurisprudenz's dogmatic thinking, or efforts to look for logical protection in the approach's mechanism. Since behind it all, the reality that occurs can actually show the creation of complicated legal bureaucratization, like no end. As a 
result, it can be increasingly distanced the lives of the nation from ideals (Asunka \& Afulani, 2018).

Second, Judicial Commission and Supreme Court as far as possible eliminate the shadows of the past and cooperate closely in a shared vision and mission and avoid the legal argumentation model that leads to; a) argumentum ad hominem, an argument based solely on considerations for attacking people / institutions directly and relying solely on interests and feelings of antipathy; b) argumentum ad ignorantiam, arguments that are based on assumptions that are not easily proven wrong, or also assumptions that are not easily proven true, c) argumentum ad populum, an error of argument because it is only concerned with public opinion and its internal collegial imagery or communal spirit.

Third, it must be understood by Judicial Commission, the imperative mandate of the law states that internally, that Judicial Commission must limit itself (self-censorship) not to be in the zone of supervision and correction of technical-judicial matters, such as providing comments on trials or decisions who have not had permanent legal force, and understand the principles and juridical commitments of supervision as mandated by the law. This means Judicial Commission is focused on monitoring things outside the course of the trial, namely the ethics and behaviour of judges. Analysis of decisions is permitted on certain terms and conditions.

Fourth, all parties should be convinced again that the existence of Judicial Commission will not disrupt the independence of judges in deciding cases (Fischer-Lescano, 2016; Salles \& Cruz, 2020). But precisely strengthen it. This was realized by Judicial Commission's commitment with the Supreme Court to maintain the independence of judges and the judiciary with the following patterns and guidelines:

1) Independent judicial power is the power in conducting judicial or judicial functions which includes the power to examine and decide on a case.

2) Independent judicial power is intended to guarantee the freedom of judges from various worries or fears caused by a decision or legal decision made.

3) Independent judicial power guarantees judges to act objectively, honestly and impartially.

4) Supervision of judicial power is solely carried out through ordinary or extraordinary legal efforts by and within the environment of the judicial authority itself. Within certain limits, it can be done by external authorities with strict rules outlined by legislation with a focus on the ethics and behaviour of judges.

5) Independent judicial authority forbids all forms of direct interference from outside the judiciary that are not stipulated by applicable law.

6) All actions against judges are carried out purely according to law.

Fifth, Judicial Commission outlines in a more straightforward manner that external supervision is oversight carried out by institutions outside the Supreme Court on the behaviour of Judges. The judge's behaviour is monitored when carrying out his duties (official) and in his daily behaviour. External supervision by Judicial Commission is carried out to strengthen internal supervision by the Supreme Court, which has been existing so far. This is under Law No. 48 of 2009 concerning Judicial Power, Law on the Supreme Court, statutory regulations related to the four jurisdictions of the judiciary under the Supreme Court, and Law on Judicial Commissions. Implementation of the supervision of judges externally by Judicial Commission carried out in three ways; 
JM. Muslimin,

Cultural Transplantation and Legal Paradox: The Case of the Indonesian Judicial Commission

Versus the Supreme Court

a. Through the receipt of public reports related to violations of the Code of Ethics (KE) and the Code of Judges Conduct (PPH). Article 22 paragraph (1) of Law No. 18 of 2011 states that in carrying out supervision, Judicial Commission receives community reports and / or information about violations of the KE and PPH. Handling community reports is a series of activities ranging from reception, deepening, panel discussion sessions (results of deepening), examinations (reporters, expert witnesses, or reported parties), and clarification of reported parties, inspection panel sessions (results of examining reporters, witnesses and / or experts), and plenary session (the results of the examination and / or clarification of the reported), and implementing the results of the session;

b. Research on court decisions that have permanent legal force. Besides receiving report from the public, Judicial Commission has the authority to supervise judges through examination of court decisions that have permanent legal force. This is not to correct or revising decisions. However, the decision analysis aims to determine the tendency of decisions of appellate court and first court judges in terms of observance of procedural law, mastery of material law, legal reasoning, and the exploration of living values in society, and describing the professionalism of judges in case resolution. In addition, the analysis of decisions that have permanent legal force is also intended for the compilation and collection of databases, both individually and collectively about appellate court judges who are worthy and potentially as Supreme Court Justices (career paths) and first court judges one day can fill the position of supreme judge. The results can be the basis for increasing the capacity of judges, and recommendations for mutations (promotion and demotion). Judicial Commission must not state judicial and substantive considerations. It is also not justified to state that decisions made by Judges are true or false, regardless of the good behaviour of the supervised Judge. Thus, the focus of Judicial Commission research is to recapitalise data, track records and strengthening meritocracy processes based on transparency, accountability and professionalism under the limits of Judicial Commission's authority;

c. Monitoring at court. It is possible for the involvement of elements of society. In this monitoring activity, Judicial Commission can establish cooperation with other agencies, Judicial Commission networks, and/or other parties. Trial monitoring at all levels of the judiciary can be carried out if there is a request for monitoring from the community or on Judicial Commission's own initiative. The object of monitoring is the trial process, the judge's behaviour, and the situation and condition of the court. The results of monitoring at the hearing will be submitted to the Supreme Court and the chair of the court monitored as an evaluation so that the same violation does not occur again, or at least can be minimized.

Sixth, in a constructive and corrective way, Judicial Commission continues to strengthen its commitment to maintain the honour, dignity and behaviour of judges. Constructively this can be realized by (for example) Judicial Commission should not stay silent in the matter of fighting for the fate and welfare of judges in budgeting. Judicial Commission should actively take part and stand in the forefront in preventing events that lead to humiliation of the judiciary and judges (contempt of court) and strive for programs that lead to maintaining the internalisation of the ethical and professional commitment of the judiciary in a preventive manner for the realisation 
of an authoritative judicial power. Corrective means to carry out the critical and independent oversight functions, as explained above.

Seventh, strengthening visionary institutional partnerships. When viewed from the organisational rules and institutional governance, Judicial Commission is the Supreme Court's external supervisory agency. Within the Supreme Court organisation itself there is a Supervisory Agency that functions to carry out functional oversight and the structure of the leadership of the Supreme Court which also carries out inherent supervision. This means the Supreme Court itself carries out an internal oversight function (J. Priban, 2017). As is also known that the position of Judicial Commission and MA in the state institutional system is equal. So, even though Judicial Commission has supervisory authority, it does not mean that supervision can be implemented with a vertical pattern (top-down supervision), but relies on the partnership and alignment supervision model (horizontal pattern). In this alignment model, the principal thing that Judicial Commission must build is the principle of critical collaboration in supervision. The principle of critical collaboration requires the independence of Judicial Commission supervision rights, but still shows an open partnership attitude to the Supreme Court. This means that the data available and generated from the MA's internal supervision, are both the data from the results of embedded supervision and functional supervision that have been carried out, as long as they are considered relevant to the external supervision function, cannot be ignored by Judicial Commission. Conversely, the Supreme Court still must respect the right of Judicial Commission to carry out its external oversight functions. With the Joint Agreement Letter (SKB) that has been agreed by both parties and the existing line of institutional authority, Judicial Commission supervision will actually maintain the integrity of honour, dignity and behaviour of judges, by providing an overview and supervision of the comparison of what has been produced by the Supreme Court. Supervision that is produced through a two-layer technique (internal supervision from the Supreme Court itself and external from the Judicial Commission) will have a dimension of objectivity and impartiality, rather than only being done through one layer. Even in the justice system there are several layers of legal remedies in the same material. The same is true in other professional world, such as in medical laboratory tests, which are often done several times for the same cases and samples. The joint decree between Judicial Commission and Supreme Court has actually led to this goal. However, there must still be a follow up and strengthening effort.

Eighth, strengthening Pancasila as a source of ethics and maximising togetherness resolution through non-legal factors by strengthening management capacity, leadership and Judicial Commission's ethical mission for community engagement and strengthening public trust. Law enforcement is not only related to juridical aspects. The task of Judicial Commission is more to the supervision and strengthening of ethical aspects. Here, matters relating to communication management, leadership, and the ethical commitment of Judicial Commission and all stakeholders absolutely need attention. Sometimes, Judicial Commission has to talk more in a focused / closed room since aspects of supervision cannot all be completely open and published in such a way. Sometimes Judicial Commission still had to focus on carrying out its supervisory functions in private. But, at the right time, if the evidence and process has become real and clear, then Judicial Commission can fulfil its public accountability task by opening wider information and partnerships with elements of the community. In short, as a state institution that carries out ethical functions, Judicial Commission is in the spotlight and high hopes to be able as a partner of the Supreme Court and all other stakeholders based on the state philosophy of Pancasila; reflecting the ethics of divinity, humanity, upholding unity, democracy and justice. 
JM. Muslimin,

Cultural Transplantation and Legal Paradox: The Case of the Indonesian Judicial Commission

Versus the Supreme Court

Ninth, one of the 'failure' of Judicial Commission is a non-empirical legal readings and horizontal and vertical communication techniques that are insensitive and down to earth. Then KY needs to be aware of the lattice and tips of applied legal communication management (Kioukies, 2020); (J. Asunka \& Patience A. A., 2018). The management relies on questions: Say what? (What message is delivered to partners?); In which channel? (What media are used?); To whom? (Who is the listener?); With what effect? (What effects are expected?); When (when? How (How to do it?); Why (Why is this done?). These questions in the legal communication management strategy are very important, because the approach to the expected effects of an ethics monitoring and enforcement activity can be of various types, namely: disseminating information, carrying out persuasion; carry out instructions; give early warning; invite joint commitment; start a new phase of collaboration; push for sanctions, etc. Calling the Chief Justice of the Supreme Court in the initial clarification process for an ethical oversight is not an effective oversight measure (Fischer-Lescano, 2016).

Tenth, communication techniques and other tips that can strengthen and are worthy to be put forward also are, smoothing communication using the approach A. A. Procedure or From Attention to Action Procedure abbreviated as AIDDA. The details are: A. Attention, I. Interest, D. Desire, D. Decision, Action. Its meaning are:

a. The phasing process starts with attention. Here, measurably, in supervising judges and ethical enforcement, Judicial Commission must be able to generate source attractiveness, and messages of urgency and proportionality in the agenda's implementation.

b. KY strives to continue to invite and create common ground or equalize the vision and mission of the Supreme Court, thus creating a commitment of togetherness.

c. In arousing attention, avoid the emergence of negative and repressive appeals, thereby fostering anxiety, worry and fear about the loss of the independence of the judicial power.

d. If attention has been raised, and togetherness strengthens, it should be followed by efforts to foster interest (interest) which is a higher degree of attention.

e. Interest is a continuation of attention, which is the starting point for the emergence of the desire (desire) to carry out an expected activity.

f. Desire alone means nothing, because it must be followed by a decision (decision), namely the decision to carry out activities (action) as expected; proportional, procedural and professional Judicial Commission and Supreme Court constructive-critical cooperation.

\section{CONCLUSION}

Law enforcement is not only introducing and copying receipt of law and establishing legal institution. It is breaking cultural regression and advancing rational approach. Weber states within a rational substance of law, there must be a rational procedure. Irrational procedures could hamper the process of law enforcement. Behind irrational procedures, one can find cultural roots. Thus, law is applied by human agency. To be effective, its cultural root should be reconstructed. The disharmony of communication and partnership between the Judicial Commission and the Supreme Court can not be resolved unless its cultural roots are invented and disclosed. The culture of corruption, ignorance of public trust, and institutional ego-centrism 
reject ethics of professionalism, transparency and mutual trust. These roots make the Indonesian legal culture runs slowly towards a real reformation.

Judicial Commission needs a breakthrough of law enforcement. It does not depend only on pure legal approach. It is based on the reform mission, as it was introduced in 1999. Historically, the existence of Judicial Commission is strong to carry out 'sacred mission'. It can't be downgraded by conservative understanding of law. Judicial Commission should extend and execute the mission by forming a grand strategy which integrates law enforcement and cultural strategy penetration. Legal paradox occurs because of the conservation of legal impunity. Supreme Court conserves itself to be the guardian of positivism. Thus, Judicial Commission should transform legal culture towards progressive approach (Cotterrell, 2017b).

Judicial Commission is not only a legal institution, but it is also an organization of reform. In order to match the target, Judicial Commission may build cooperation to other civil organizations and launch a new approach of creative communication skills of reform movement based on the theories of attention, intention, desire, decision and action (J. Asunka \& Patience A. A., 2018).

\section{REFERENCE}

Algra, N., \& H. J. (1981). Rechtsingang. Groningen: Wolters-Noordhoff.

Asunka, J., \& Afulani, P. A. (2018). Politics and Public Service Provision in Africa's New Democracies. International Journal of Politics, Culture and Society, 31(3), 207-227.

Chambliss, W. J., \& Seidman, R. B. (1971). Law, Order and Power. Addison-Wesley Publishing Company.

cnnindonesia. (2015). Komisi Yudisial akan Periksa Hakim Sarpin. Maret, 31. http://www.cnnindonesia.com/nasional/20150331153500-12-43257/komisi-yudisialakan-periksa-hakim- sarpinlusa/

Cotterrell, R. (2017). Theory and Values in Socio-Legal Studies. Journal of Law and Society, $44(1), 19-36$.

Detik. (2005a). Komisi Yudisial Periksa Hakim PT Jabar. 29, Agustus. http://news.detik.com/read/2005/08/29/104735/431009/10/komisi-yudisial-periksahakim-pt-jabar-satu- lawansatu?nd771104bcj

Detik. (2005b). Masih Penasaran, KY Surati Lagi Bagir Manan. 27, Desember.

Detik. (2006). Diperiksa KY Kasus Arthaloka, Hakim Agung Harifin Mangkir Lagi. 7, Februari. http://news.detik.com/index.php/detik.read/tahun/2006/bulan/02/tgl/07/time/ 181317/idnews/534425/idkanal /10

Detik. (2015). Hakim Agung Dinner dengan Terdakwa Korupsi, Ketua MA Langsung Ke Pak Timur. 17, Maret. http://news.detik.com/read/2015/03/17/132619/2861038/10/hakimagung-dinner-dengan- terdakwakorupsi-ketua-ma-langsung-ke-pak-timur?nd771104bcj

Dias, R. W. M. (1976). Jurisprudence. Butterworths. 
JM. Muslimin,

Cultural Transplantation and Legal Paradox: The Case of the Indonesian Judicial Commission

Versus the Supreme Court

Fischer-Lescano, A. (2016). Sociological Aesthetics of Law. Law, Culture and the Humanities, $16(2), 268-293$.

Friedman, L. M. (1977). Law and Society. Prentice Hall.

Hukumonline. (n.d.). Koalisi Pemantau Peradilan (MaPPI FH UI, ICW, LeIP, ICEL, PSHK, YLBHI, ICJR dan ILR), Memahami Komisi Yudisial Sebagai Upaya Mencari Sosok Komisioner Komisi Yudisial Yang Ideal.

Hukumonline. (2006). Hakim Agung Dipastikan Mengambil Langkah Hukum. 1, Februari.

Kelsen, H. (1979). What is Justice. University of California Press.

Kioukies, D. K. (2020). The Philosophy and Possible Inadequacies of Crisis Governance. International Journal of Law and Society, 3(2), 102-105.

Kompas. (2007). Survei Transparansi Internasional Indonesia: Polisi, Pengadilan, DPR Lembaga Terkorup. 28, Februari. nasional.kompas.com\%3ENews\%3ENasional

Kompas. (2015). KPK Periksa Hakim Agung Timur Manurung Terkait Kasus Bos Sentul City. 13, Januari.

Merdeka. (2005). KPK Periksa Hakim Agung Timur Manurung Terkait Kasus Bos Sentul City. 24, Oktober. http://nasional.kompas.com/read/ 2015/01/13/1105012/

Priban, J. (2017). A Sociology of Legal Distinctions: Introducing Contemporary Interpretations of Classic Socio-Legal Concepts. Journal of Law and Society, 44(1), 1-18.

Radbruch, G. (1961). Einführung in die Rechtswissenschaft. Koehler.

Rahardjo, S. (2002). Polisi Sipil Dalam Perubahan Sosial di Indonesia. Penerbit Buku Kompas.

Raz, J. (1973). The Concept of a Legal System: An Introduction to the theory of Legal Systems. Oxford University Press.

Republika. (2017). Polisi Lembaga Terkorup di Indonesia. 7, Maret. nasional.republika.co.id\%3Enews\%3ENasional

Salles, B. M., \& Cruz, P. M. (2020). Access to Justice: Legal Concept and Characterization. International Journal of Law and Society, 3(3), 106.

Suaramerdeka. (2005). Bagir Di-deadline Komisi Yudisial. 28, Desember.

Tim Penyusun. (2005). Ayo, Lawan Korupsi. LBH-P2i Makasar-Partnership.

Zakiyah \& dkk. (2003). Menyingkap Tabir Mafia Peradilan. ICW.

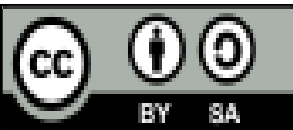

(C) 2021 by JM. Muslimin

This work is an open access article distributed under the terms and conditions of the

Creative Commons Attribution-Share Alike 4.0 International License (CC BY SA) 